\title{
ECONOMIC SECURITY SERVICE AS A GUARANTOR OF PROTECTION OF BUSINESS ACTIVITY OF THE BUSINESS ENTITY
}

In today's aggressive competitive environment in a limited resource base, each business entity must take care of its economic security. The Economic Security Service acts as a guarantor of the protection of its business activities. The protection of the business activity of the business entity is to organize reliable protection of its property and property rights, continuous monitoring and classification of external and internal threats and destabilizing effects in order to minimize or eliminate them. security through the use of an appropriate mechanism. The article is devoted to the definition and justification of the main directions, functions and methods of work of the economic security service of the subject entrepreneurship. The purpose of the article is to identify and justify the main areas functions and methods of work of the economic security service of the business entity. The object of the study is to ensure the economic security of economic entities in conditions of economic instability. The subject of research - the organization of the economic security service as a guarantor of business protection. The standard structure of service of economic safety is offered, appointment of its structural divisions is considered. Typical objects that are part of the professional interests of employees of the economic security service of the enterprise are identified. Mandatory measures to ensure economic security and criteria for selection of personnel of the economic security service are substantiated. Further research in this area should be aimed at preparing materials for the legislative consolidation of the status of the economic security service as a guarantor of the protection of business activities of the entity. It is stated that business entities and public authorities should jointly develop an effective mechanism for involving their own security services in the protection of property and business interests of enterprises. Cooperation of the state as a regulator of economic relations with business entities in the field of economic security of business creates favorable conditions for sustainable development of the business sector, reduces the burden on state law enforcement agencies.

Key words: economic security, economic security service, principles, functions, mechanism of economic security, professional interests.

DOI: https://doi.org/10.32838/2523-4803/70-3-34

УДК 336.717:338.5

Ясінська А.І.

кандидат економічних наук, доцент,

Національний університет «Львівська політехніка»

Yasinska Alla

Lviv Politechnic National University

\section{СИСТЕМНО-ОРІЕНТОВАНИЙ ПІДХІД ЩОДО УПРАВЛІННЯ ТРАНСАКЦІЙНИМИ ВИТРАТАМИ ПІДПРИЕМСТВА}

У статті досліджено необхідність управління трансакційними витратами підприємства. Обгрунтовано актуальність проблеми щуодо побудови системи управління трансакційними витратами підприємства. Розглянуто сутність управління иими витратами з позиції системно-орієнтованого підходу для отримання оптимального результату від їхнього здійснення. За принципами побудови кібернетичної моделі управління сформовано узагальнену модель системно-орієнтованого управління трансакиійними витратами та визначено основні ї̈ складники. У иій моделі особливу увагу приділено функиіям управління, зокрема визначено основні завдання щзодо управління трансакційними витратами для ефективної реалізаџії кожної з циих функцій. Сформовано основні напрями щзодо визначення ефективності системно-оріснтованого управління трансакційними витратами.

Ключові слова: управління, трансакційні витрати, системно-орієнтоване управління, функиії управління, модель.

Постановка проблеми. Швидкоплинні умови господарської діяльності вітчизняних підприємств та складність умов середовища, в якому вони функціонують, значною мірою впливають на їхні фінансові результати. Забезпечення належного рівня фінансової стабільності можливе тільки завдяки використанню дієвих інструментів управління витратами 3 метою їх оптимізації. Порівняння величини доходів та понесе- 
них витрат на їх здійснення є найважливішим питанням на кожному підприємстві. Проте чільне місце у складі всіх витрат підприємства варто виділити трансакційним, оскільки в умовах стрімкого розвитку їх неможливо уникнути, а їхня величина має тенденцію до зростання. Система управління підприємством, а також система управління витратами досліджувалися науковцями та практиками впродовж багатьох років. Проте в основному трансакційні витрати були поза увагою, і традиційно склалася думка, що такий вид витрат необхідно скорочувати. Вирішення проблеми, таким чином, $\epsilon$ суперечливим рішенням, тому що повністю уникнути трансакційних витрат без шкоди i негативних наслідків для господарської діяльності підприємства практично неможливо.

Аналіз останніх досліджень і публікацій. Витрати підприємства є одним з основних об'єктів у системі управління підприємством, і тому їх дослідженню в різних аспектах присвячено чимало праць вітчизняних і зарубіжних науковців. Дедалі більшої актуальності набуває питання управління трансакційними витратами, які виникають у різних сферах господарської діяльності (операційній, фінансовій, інвестиційній) від моменту створення і до моменту ліквідації підприємства. Дослідженню теоретичних, методичних та методологічних проблем управління трансакційними витратами присвятили свої праці такі науковці, як: Л.В. Базалієва [1], О. Вільямсон [2], Р. Коуз [3], П.В. Круш [4], І.В. Макалюк [4, 5], Д. Норд [6], Ж.М. Ющак [8]. Проте, віддаючи належне науковим напрацюванням, слід зазначити, що системному підходу щодо управління трансакційними витратами не приділено належної уваги. Зокрема, є потреба у більш детальному вивченні питання щодо складників системи, основних іï елементів для забезпечення ефективної оптимізації цих витрат та прийняття управлінських рішень, повязаних з управління ними.

Формулювання цілей статті. Мета статті полягає у дослідженні сутності системно-орієнтованого підходу щодо управління трансакційними витратами підприємства, визначенні основних елементів та складників узагальненої моделі управління, а також формуванні основних завдань для реалізації специфічних функцій управління, які властиві трансакційним витратам.

Виклад основного матеріалу. Традиційні методи та моделі ведення бізнесу сьогодні потребують значної трансформації. Істотні зміни, які відбуваються сьогодні в інформаційному середовищі, охоплюють найрізноманітніші сфери життєдіяльності. Кардинальні зміни можна спостерігати у системі прогнозування подій, плануванні умов обслуговування потреб - бізнесу, побуту, праці, дозвілля тощо. Створення ефективних систем управління орієнтоване на оптимізацію бізнес-процесів шляхом застосування новітніх інформаційних технологій (IT) і використання цифрових технологій (digital), які покликані забезпечити економічну доцільність та привабливість споживання.
Звичайно, всі ці заходи спрямовані на досягнення ефективності господарської діяльності, яка повинна забезпечити фінансовий результат, тому в системі управління підприємством необхідно особливу увагу приділити управлінню витратами, зокрема й трансакційними.

Трансакційні витрати є специфічними, чинними нормативними положеннями не передбачено і чітко не визначено їх відображення в системі бухгалтерського обліку. Тому більшою мірою облік трансакційних витрат зумовлений інформаційними потребами для управління підприємством, і більш детальну інформацію про склад, розмір та місце їх виникнення можна отримати 3 даних управлінського обліку. Більшість трансакційних витрат є накладними і непрямими, тому ïx відображення саме в системі управлінського обліку дає змогу здійснювати ефективне управління ними.

Автор концепції трансакційних витрат Р. Коуз трактує поняття “трансакційні витрати” як витрати, повязані зі збиранням та обробкою інформації, проведенням переговорів та прийняттям рішення, контролем та юридичним захистом виконання контрактів в умовах ринку [3]. Вітчизняними і зарубіжними науковцями запропоновано низку дефініцій цього поняття, які відрізняються як за змістом, так і за типологією. Поряд із цим майже всі науковці, які досліджують трансакційні витрати, мають одностайну думку щодо виникнення витрат: виникають вони на всіх стадіях кругообігу всіх суб'єктів господарювання, й уникнути їх неможливо.

Формування механізму управління трансакційними витратами на вітчизняних підприємствах, а також методичний інструментарій оцінювання ефективності управління цими витратами висвітлено у працях П.В. Круш [4] та I.В. Макалюк [4, 5]. Зокрема, авторами визначено основні елементи механізму, завдання i принципи управління трансакційними витратами, функції та інструменти. Процес управління трансакційними витратами через систему реалізації функцій управління (планування, організування, мотивування, контролювання та регулювання) досліджується у працях І.В. Макалюк, яка наголошує, що послідовне та комплексне виконання функцій управління забезпечуватиме перетворення вихідних ресурсів у кінцевий результат, а також досягнення цілей управління. Окрім запропонованих автором функцій менеджменту в системі управління трансакційними витратами, їх варто доповнити специфічними функціями управління, які притаманні саме витратам, що дасть змогу детальніше вивчити склад, структуру, поведінку та місце виникнення цих витрат, що в подальшому повинні забезпечити їх оптимізацію.

Дослідженню теоретичних та організаційно-методичних аспектів бухгалтерського обліку і контролю трансакційних витрат присвячено праці Ж.М. Ющак [8]. Зокрема, автором визначено напрями удосконалення організації бухгалтерського обліку та внутрішнього контролю трансакційних витрат, для цілей бухгалтерського обліку та управління удосконалено 
класифікацію і запропоновано комплексний підхід щодо їх облікового відображення у звітності.

Питанням управління трансакційними витратами підприємства присвячені праці Л.В. Базалієвої [1]. Зокрема, автор досліджує науково-теоретичні та методичні основи управління трансакційними витратами, особливості їхнього формування та управління, висвітлює економічну сутність трансакційних витрат як об'єкта управління з позицій поєднання функціонального, системного та стратегічного підходів. Погоджуючись із дослідженнями автора Л.В. Базалієвої, слід зазначити, що саме поєднання функціонального та системного підходів повинно забезпечити ефективність системи управління трансакційними витратами, досягнення якої неможливе без реалізації основних функцій менеджменту. Вирішення завдання щодо реалізації функцій менеджменту є складним і потребує більш детальних досліджень у процесі визначення конкретних заходів, які повинні враховувати специфіку саме трансакційних витрат на підприємстві.

Управління трансакційними витратами підприємства - це досить складний, динамічний і деякою мірою неоднозначний процес, метою якого є оптимізація цього виду витрат, яка повинна забезпечити фінансовий результат із виправданими витратами. Тому, на нашу думку, сутність управління трансакційними витратами необхідно розглядати, використовуючи системно-орієнтований підхід, який полягає у дії двох взаємопов'язаних підсистем - керуючої (об'єкти управління) та керованої (суб'єкти управління). Системно-орієнтований підхід щодо управління трансакційними витратами дає змогу визначити сутність цих витрат, місце виникнення, основні завдання та цілі, вибрати відповідні методи та інструменти, сформувати інформаційну базу задля оцінки ефективності управління ними, а також прийняття оперативних $\mathrm{i}$ стратегічних управлінських рішень. 3 метою побудови ефективної системи управління трансакційними витратами вітчизняні науковці [1-3] пропонують застосування системного, функціонального та стратегічного підходів. Всі запропоновані підходи є взаємопов'язаними, i тому створення раціональної системи, яка повинна забезпечити ефективність свого функціонування, досягнення цілей та завдань, взаємодію елементів і складників, реалізацію стратегічних і тактичних завдань, функцій, принципів, методів та інструментів, необхідно розглядати з позицій системного підходу, зорієнтованого на поєднання наведених підходів, але враховуючи специфіку як діяльності підприємства, так і трансакційних витрат задля забезпечення оптимального їх співвідношення.

Сутність системно-орієнтованого управління трансакційними витратами підприємства полягає у дослідженні взаємодії та удосконаленні елементів системи, які, орієнтуючись на виконання мети, змінюють свій стан під впливом зовнішніх і внутрішніх факторів для отримання оптимального результату від здійснення витрат. Кожен об’єкт, стосовно якого приймається управлінське рішення, розглядається з погляду системного підходу, що в подальшому дасть змогу підвищити рівень розуміння процесу управління трансакційними витратами і тим самим забезпечити його чітку координацію, цільове спрямування та сприятиме досягненню поточних та стратегічних результатів господарської діяльності підприємства. В основу системно-орієнтованої моделі покладено принцип побудови кібернетичної моделі управління, в якій основними елементами системно-орієнтованого управління трансакційними витратами є:

1. Вхід системи - джерела ресурсів: постачальники, кредитні та банківські установи, науководослідні організації тощо. Види ресурсів: фінансові, матеріальні, інформаційні, трудові, використовувані технології, науково-дослідні розробки, дослідно-конструкторські розробки, інновації тощо.

2. Фактори впливу зовнішнього щодо підприємства середовища.

3. Керуюча підсистема (суб'єкти управління) власники, менеджери, управлінці, фахівці різних рівнів управління.

3.1. Мета управління трансакційними витратами.

3.2. Підсистема стратегічного управління - довготермінові цілі, стратегія, політика.

3.3. Підсистема тактичного управління - короткотермінові цілі, тактика, завдання.

3.4. Специфічні функції управління трансакційними витратами: прогнозування, планування, організування, нормування, калькулювання, облік, аналізування, мотивування, контролювання, регулювання, координування.

3.5. Методи управління трансакційними витратами: стратегічні та тактичні.

3.6. Інструменти управління трансакційними витратами: фінансові, цінові, логістичні, техніко-технологічні, адміністративні, соціальні тощо.

4. Керована підсистема (об’єкти управління):

4.1. Об'єкти управління - трансакційні витрати: за видами діяльності (в операційній, фінансовій, інвестиційній, надзвичайній діяльності); за підрозділами, процесами, місцями виникнення тощо.

4.2. Фактори впливу внутрішнього середовища (фінансові, виробничі, ресурсні, управлінські, інформаційні).

4.3. Власний потенціал (виробничий, кадровий, технологічний, фінансовий, інноваційний, інформаційний тощо).

5. Вихід системи - фінансовий та інший результат діяльності підприємства.

Для дослідження особливостей системно-орієнтованого управління трансакційними витратами підприємства пропонується використання узагальненої моделі, наведеної на рис. 1.

Основною метою системно-орієнтованого управління трансакційними витратами $є$ їх оптимізація, яка досягається шляхом удосконалення ефективності процесу управління та реалізації основних функцій управ- 


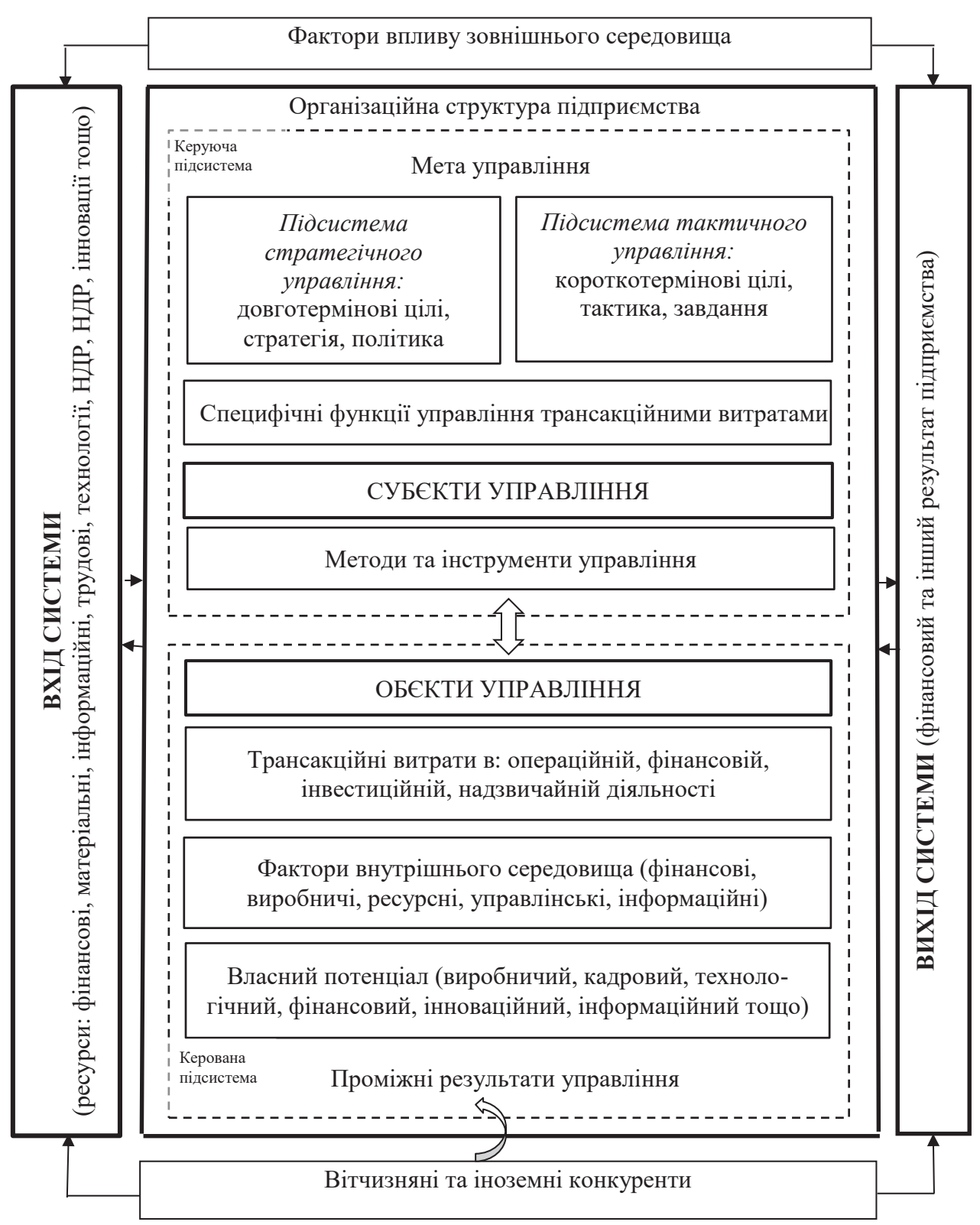

Рис. 1. Модель системно-оріснтованого управління трансакційними витратами підприємства

Примітка: сформовано на підставі матеріалів авторських досліджень [7]

ління. Функції управління трансакційними витратами слід розглядати через призму загальних функцій менеджменту із доповненням специфічних для витрат: планування, нормування, калькулювання, облік, аналіз тощо. Для забезпечення ефективності реалізації та чіткого виконання функцій у процесі управління слід сформувати та визначити основні завдання, які необхідно вирішити для того, щоб забезпечити оптимальний рівень трансакційних витрат, своєчасно розробити заходи і за потреби усунути недоліки шляхом прийняття відповідних управлінських рішень. У моделі системно-орієнтованого управління трансакційними витратами ключове місце в керуючій підсистемі варто виділити функціям управління, реалізація яких сприятиме усвідомленню управлінського персоналу щодо постановки і виконання конкретних завдань, які стосуватимуться трансакційних витрат (табл. 1).

Варто зазначити, що наведені основні завдання щодо реалізації специфічних функцій у системноорієнтованому управлінні трансакційними витратами $\epsilon$ узагальненими, і для більш точного та конкретизованого їх формування необхідно враховувати особливості діяльності кожного окремого підприємства та види трансакційних витрат. Окрім того, необхідно також враховувати тенденції внутрішнього та зовнішнього середовища функціонування, а також вплив чинників на величину трансакційних витрат з урахуванням ступеня їхньої вагомості. Тому основними напрямами щодо визначення ефективності системно-орієнтованого управління трансакційними витратами є: 
Основні завдання специфічних функцій у системно-орієнтованому управлінні трансакційними витратами

\begin{tabular}{|c|c|}
\hline Функції управління & Основні завдання щодо управління трансакційними витратами \\
\hline Прогнозування & $\begin{array}{l}\text { прогнозування планових параметрів та показників, які визначатимуть результативність господарської } \\
\text { діяльності; } \\
\text { аналіз ретроспективних даних, тенденцій їхньої зміни для прогнозування фінансово-господарської } \\
\text { діяльності підприємства на майбутній звітний період; }\end{array}$ \\
\hline Планування & $\begin{array}{l}\text { збір, обробка, інтерпретація управлінської інформації; } \\
\text { аналіз впливу чинників зовнішнього та внутрішнього підприємницького середовища на величину } \\
\text { трансакційних витрат; } \\
\text { планування та визначення економічного обгрунтованої величини та складу трансакційних витрат на } \\
\text { плановий період; } \\
\text { складання бюджетів та поточних планів трансакційних витрат; }\end{array}$ \\
\hline Організування & $\begin{array}{l}\text { формування організаційного механізму управління трансакційними витратами; } \\
\text { розподіл повноважень, визначення відповідальних осіб щодо здійснення трансакційних витрат на } \\
\text { різних рівнях управління; } \\
\text { удосконалення інформаційної бази та системи управління загалом з метою прийняття стратегічних, } \\
\text { тактичних та оперативних управлінських рішень; }\end{array}$ \\
\hline Нормування & $\begin{array}{l}\text { визначення та встановлення обгрунтованих нормативів щодо складу трансакційних витрат в } \\
\text { операційній діяльності підприємства; } \\
\text { визначення чинників (зовнішніх, внутрішніх) впливу на виробничу та господарську діяльність } \\
\text { підприємства; }\end{array}$ \\
\hline Калькулювання & $\begin{array}{l}\text { обгрунтування розрахунків витрат пов’язаних із виготовленням продукції (робіт, послуг); } \\
\text { аналіз витрат з визначенням чинників впливу на відхилення; } \\
\text { розроблення заходів щодо усунення відхилень; }\end{array}$ \\
\hline Облік & $\begin{array}{l}\text { накопичення та узагальнення інформації (бухгалтерська, фінансова, статистична, податкова, } \\
\text { управлінська звітність підприємства, інша звітність відділів, центрів відповідальності тощо); } \\
\text { контроль трансакційних витрат з метою визначення їхньої доцільності; }\end{array}$ \\
\hline Аналізування & $\begin{array}{l}\text { визначення ефективності використання ресурсів } \\
\text { визначення чинників впливу (зовнішніх і внутрішніх) на склад і величину трансакційних витрат; } \\
\text { виявлення резервів зниження витрат, причини перевитрат; } \\
\text { дослідження інформації для прийняття управлінських рішень щодо планування трансакційних } \\
\text { витрат; }\end{array}$ \\
\hline Мотивування & $\begin{array}{l}\text { пошук та застосування методів зниження витрат; } \\
\text { спонукання працівників до оптимізації чи дотримання встановленого рівня витрат; } \\
\text { створення та удосконалення існуючої системи заходів (спонукальних мотивів) спрямованих на } \\
\text { матеріальне стимулювання праці працівників; } \\
\text { зацікавленість працівників у здійсненні трудової діяльності; }\end{array}$ \\
\hline Контролювання & $\begin{array}{l}\text { аналіз встановлених нормативів на відповідність та умов дотримання; } \\
\text { виявлення відхилень фактичних від запланованих показників } \\
\text { визначення умов дотримання нормативів або їхньої зміни; } \\
\text { контроль витрат на початковому, в процесі та на кінцевому етапах; }\end{array}$ \\
\hline Регулювання & $\begin{array}{l}\text { визначення та усунення відхилень виявлених на етапі контролю шляхом впровадження відповідних } \\
\text { заходів; } \\
\text { своєчасне регулювання витрат, виправлення помилок задля досягнення запланованих показників та } \\
\text { результатів; }\end{array}$ \\
\hline Координування & $\begin{array}{l}\text { узгодження взаємовідносин між окремими центрами відповідальності на різних рівнях управління } \\
\text { із зовнішнім щодо підприємства середовищем; }\end{array}$ \\
\hline
\end{tabular}

- рівень досягнення цілей, на які спрямовувалися трансакційні витрати. У ситуаціях, коли найважливішим є досягнення конкретної мети в чітко визначений термін, вважається несуттєвим фактором, коли витрати на досягення мети перевищують отримані доходи;

- співвідношення отриманого результату та понесених трансакційних витрат на його досягнення. Досить часто керівництво підприємства орієнтується лише на отримання максимального результату за мінімальних витрат, хоча такий підхід не є доцільним в усіх випадках;

- тенденції зміни непродуктивних витрат (більшість трансакційних витрат $€$ непродуктивними).
Стійка динаміка зменшення непродуктивних витрат дає можливість стверджувати про оптимізацію різних процесів, пов'язаних 3 використанням ресурсів на підприємстві;

- показники оцінювання ефективності управління трансакційними витратами, пов'язаними 3 виробничим процесом. Доцільним є аналізування окремих елементів витрат 3 метою деталізованого виявлення всіх причин, що зумовили позитивні та негативні зміни виробничих, невиробничих витрат тощо;

- інтегральний показник ефективності управління трансакційними витратами підприємства. Якщо різні одиничні показники набувають протилежних значень 
на конкретний момент часу, то для прийняття оперативного управлінського рішення потрібно мати узагальнену оцінку ефективності управління.

Висновки. Процес управління господарською діяльністю підприємства неможливий без виникнення трансакційних витрат, тому питання та проблеми щодо їх дослідження не можуть бути залишені поза увагою управлінців і $є$ сьогодні надзвичайно актуальними. Комплексність та узгодженість прийняття управлінських рішень, пов'язаних з управлінням трансакційними витратами, можуть бути забезпечені за умови використання системного підходу, що дасть змогу не тільки унеможливити збитковість підприємства, але й підвищити його платоспроможність, дохідність, фінансову незалежність та стабільність розвитку.

Науковою новизною статті $є$ вдосконалення процесу управління трансакційними витратами 3 позицій використання системно-орієнтованого підходу, який дасть змогу забезпечити отримання бажаних результатів та покращити систему управління підприємства загалом. Для удосконалення та забезпечення ефективності результативних показників необхідна реалізація специфічних функцій управління витратами, зокрема визначення основних завдань у процесі реалізації кожної з функцій, що дасть змогу перетворити вхідні ресурси (фінансові, матеріальні, інформаційні, трудові), використовувані технології, інновації в кінцевий результат - оптимізовані трансакційні витрати підприємства.

Перспективою подальших наукових досліджень $є$ розроблення методики показників оцінювання ефективності управління трансакційними витратами (інтегрального показника), визначення основних критеріїв, параметрів, інструментів, які будуть дієвими і забезпечуватимуть досягнення мети та завдань, а в кінцевому результаті - оптимізовані трансакційні витрати.

\section{Список літератури:}

1. Базалієва Л.В. Науково-теоретичні та методичні основи управління трансакційними витратами підприємства : монографія. Харків : ХНЕУ, 2009. 164 с.

2. Вільямсон О.Е. Економічні інституції капіталізму: Фірми, маркетинг, укладання контрактів / пер. 3 анг. С. Бушуєва. Київ : АРТЕК, 2001. 472 с.

3. Коуз Р. Фирма. Рынок. Право / пер. з анг. Б. Пинскера. Москва : Дело, 1993. 192 с.

4. Круш П.В., Макалюк І.В. Формування механізму управління трансакційними витратами підприємства. Економічний вісник НТУУ «КПI». 2013. № 10. С. 212-218.

5. Макалюк І.В. Методичний інструментарій оцінювання ефективності управління трансакційними витратами машинобудівних підприємств. Економічний вісник НТУУ «КПІ». 2015. № 12. С. 213-224.

6. Норд Д. Інституції, інституційна зміна та функціонування економіки / пер. 3 анг. І. Дзюб. Київ : Основи, 2000. 198 с.

7. Партин Г.О., Ясінська А.І. Системно-орієнтоване управління витратами промислового підприємства : монографія. Львів : ЗУКЦ ПП НВФ Біарп, 2011. 200 с.

8. Ющак Ж.М. Внутрішній контроль трансакційних витрат в системі управління: організаційно-методичне забезпечення. Економічний аналіз. 2010. - Вип. 6. С. 540-544.

\section{References:}

1. Bazaliieva L.V. (2009). Naukovo-teoretychni ta metodychni osnovy upravlinnia transaktsiinymy vytratamy pidpryiemstva [The Scientific-theoretical and Methodical Management Bases of Transactional Expenses of the Enterprise]. Kharkiv. (in Ukrainian).

2. Williamson O.E. (2001) Ekonomichni instytutsii kapitalizmu: Firmy, marketynh, ukladannia kontraktiv [The Economic Institutions of Capitalism: Firms, Markets, Relational Contracting]. Kyiv : ARTEK (in Ukrainian).

3. Kouz R. (1993) Fyrma. Rыnok. Pravo [The Nature of the Firm. Marketing. Law]. Moskow : Delo (in Russian)

4. Krush P.V., Makaliuk I.V. (2013) Formuvannia mekhanizmu upravlinnia transaktsiinymy vytratamy pidpryiemstva [Formation of the Management Mechanism of Transactional Expenses of the Enterprise]. Ekonomic bulletin NTUU KPI, no. 10 , pp. $212-218$ (in Ukrainian).

5. Makaliuk I.V. (2015) Metodychnyi instrumentarii otsiniuvannia efektyvnosti upravlinnia transaktsiinymy vytratamy mashynobudivnykh pidpryiemstv [Methodological Instrumentarium for Evaluation of Management Efficiency of Transactional Expenses of Machine-building Enterprises]. Ekonomic bulletin NTUU KPI, no. 12, pp. 213-224 (in Ukrainian).

6. North D. (2000) Instytutsii, instytutsiina zmina ta funktsionuvannia ekonomiky [The Institutions, Institutional Change and Economic Performance]. Kyiv : Osnovy (in Ukrainian).

7. Partyn H.O., Yasinska A.I. (2011) Systemno-oriientovane upravlinnia vytratamy promyslovoho pidpryiemstva [System-oriented expenses management of an industrial enterprise]. Lviv (in Ukrainian).

8. Yushchak Zh.M. (2010) Vnutrishnii kontrol transaktsiinykh vytrat v systemi upravlinnia: orhanizatsiino-metodychne zabezpechennia [Internal control of transactional expenses in the management system: organizational and methodical support]. Economic analysis, vol. 6, pp. 540-544 (in Ukrainian). 


\section{СИСТЕМНО-ОРИЕНТИРОВАННЫЙ ПОДХОД К УПРАВЛЕНИЮ ТРАНСАКЦИОННЫМИ ИЗДЕРЖКАМИ ПРЕДПРИЯТИЯ}

В статье исследована необходимость управления трансакционными издержками предприятия. Обоснована актуальность проблемы по построению системы управления трансакционными издержками предприятия. Рассмотрена сущчность управления этими затратами с позиций системно-ориентированного подхода для получения оптимального результата от их осуществления. По приниипам построения кибернетической модели управления сформирована обобщенная модель системно-ориентированного управления трансакционными издержками и опеределены основные ее составляющие. В этой модели особое внимание уделено функциям управления, опеределены основные задачи по управлению трансакционными издержками для эффективной реализации каждой из этих функций. Сформированы основные направления по определению эффективности системно-ориентированного управления трансакционными издержками.

Ключевые слова: управление, трансакционные издержки, системно-ориентированное управление, функции управления, модель.

\section{THE SYSTEM-ORIENTED APPROACH TO MANAGEMENT OF TRANSACTIONAL EXPENCES OF THE ENTERPRISE}

The article examines the relevance of the transaction expenses management of the enterprise. It substantiated the urgency of the problem on building the management system of transactional expenses of the enterprise, the functioning of which should ensure the enterprise's strategic and tactical management decisions, and ultimately not only expenses optimization, but also increase other financial indicators. It considered the essence of expenses management the provision of the system-oriented approach for obtaining of optimal result from their implementation. The generalized model of systemoriented management of transactional expenses was formed according to the principles of cybernetic management model construction. The basic elements of the system-oriented management model of transactional expenses, in particular the input (sources and types of resources) and output (financial and other result of activity of the enterprise) of the system were defined. In a managing subsystem (management entity) it is allocated subsystems of strategic and tactical management (their purposes, strategy, policy, tasks) which interaction with a managing subsystem (management entity) and is carried out by realization of corresponding functions, methods, tools in consideration of available potential (industrial, personnel, technological, financial, innovative, resource, information) and taking into account the influence of factors of external and internal environment. This model focuses on management functions that include forecasting, planning, organizing, rationing, calculating, accounting, analysis, motivation, control, regulation and coordination. The main tasks on transactional expenses management were formed in order to ensure effective implementation each of the above functions. The principal directions for determining the effectiveness of system-oriented management of transaction expenses were identified, on the basis of which it is possible to comprehensively solve the performance tasks, evaluate and develop efficiency indicators that should ensure the enterprise's profit and stability.

Key words: management, transaction expenses, system-oriented management, management functions, model. 